\title{
PENGARUH PEMBERIAN EKSTRAK KACANG HIJAU (Vigna radiata)TERHADAP ORGANOLEPTIK NATA DE CASSAVA DARI LIMBAH KULIT SINGKONG
}

\author{
Yuslim Fauziah $^{1)}$, Sri Wahyuningsih ${ }^{2)}$ \\ E-mail: sriw396@gmail.com \\ ${ }^{1)}$ Program Studi Pendidikan Biologi, FKIP Universitas Riau
}

\begin{abstract}
:
Nata de cassava is a type of food made from a substrate or liquid derived from the by-product of cassava processing by utilizing the Acetobacter xylinum bacteria. This research was conducted to determine the effect of mung bean extract on the quality of Nata de cassava and poster design of biotechnology subject matter at the XII grade high school level in June-August 2020. This research was conducted in 2 stages, namely the experimental stage: the effect of giving mung bean extract to the quality of Nata de Cassava and the second stage of poster design: analysis of the potential development of biotechnology teaching materials for class XII high school level. This study used an experimental method by conducting experiments at the Laboratory of the Faculty of Mathematics and Natural Sciences (FMIPA), Pekanbaru. Sampling was carried out with a completely randomized design (CRD) consisting of 4 treatments and 3 replications. The parameters in this study were thickness analysis and acidity $(\mathrm{pH})$ analysis. Based on the results of the Analysis of Variance (ANOVA) at the 5\% level, giving green bean extract showed a significant effect on the quality of Nata de cassava. Giving green bean extract of $600 \mathrm{ml}$ gives an increase in the quality of the best Nata de cassava and based on the analysis of the potential research results can be used as a poster design for class XII high school level biotechnology material.
\end{abstract}

KeyWords: Quality Nata de Cassava, Poster design, Mung bean extract

\section{PENDAHULUAN}

Nata de cassava adalah jenis makanan pencuci mulut berbentuk gel, berwarna putih agak transparan, memiliki tekstur kenyal terbuat dari substrat atau cair yang berasal dari hasil samping pengolahan singkong dengan memanfaatkan bakteri Acetobacter xylinum (Departemen Pertanian, 2011). Menurut Hersoelistyorini dalam Dewi Lestari, dkk (2018) kandungan karbohidrat yang terdapat dalam kulit singkong sebesar 4,55\%. Kandungan karbohidrat dalam kulit singkong dapat digunakan mikroorganisme Acetobacter xylinum untuk pertumbuhan menghasilkan produk fermentasi berupa nata (Hersoelistyorini dalam Dewi Lestari, dkk., 2018).
Proses pembuatan nata membutuhkan media yang mengandung nitrogen dan karbon. Pada penelitian ini sumber nitrogen yang digunakan yaitu kacang hijau (Vigna radiata). Kacang hijau memiliki kandungan gizi seperti: energi, protein, lemak, karbohidrat, kalsium, fosfor, besi, vitamin $\mathrm{A}$, vitamin $\mathrm{B} 1$, dan vitamin $\mathrm{C}$ (Wita Dola Rista Sidabutar direktorat, 2013).

Penelitian yang telah dilakukan oleh Dewi Lestari, dkk (2018) sebelumnya, Dewi Lestari menggunakan limbah padat dari singkong yaitu kulit singkong sebagai substrat dalam pembuatan Nata yang menggunakan sumber nitrogen anorganik yaitu ZA yang mana berfungsi untuk merangsang pertumbuhan dan aktivitas bakteri Acetobacter xylinum sebagai sumber nitrogen dan menunjukkan bahwa limbah kulit 
singkong berpengaruh terhadap kualitas dalam pembuatan Nata de cassava dengan volume kulit singkong $1000 \mathrm{ml}$, akan tetapi masih menggunakan sumber nitrogen anorganik seperti ZA sedangkan Menurut Elvi Rahmadani, dkk (2017) penggunaan ZA sebagai bahan tambahan makanan dinilai kurang aman. Sejak tahun 2006 FAO sudah tidak merekomendasikan lagi penggunaan ZA maupun urea sebagai bahan tambahan makanan. Pemerintah juga telah melarang penggunaan pupuk ZA yang tertuang dalam PK BPOM RI NO 72015 maka harus ada alternatif bahan pengganti ZA yang alami dan aman dalam pembuatan nata yaitu kacang hijau. Dengan hal itu, penulis ingin melakukan penelitian pembuatan Nata de cassava yang menggunakan limbah padat yaitu kulit singkong dengan memberikan penambahan ekstrak kacang hijau sebagai sumber nitrogen organik yang akan menghasilkan organoleptik yang baik daripada menggunakan sumber nitrogen anorganik. Menurut penulis hal ini dapat dicapai dengan memberikan konsentrasi ekstrak kacang hijau yang berbeda-beda sehingga metabolisme bakteri Acetobacter xylinum dapat berkembang dengan baik dan tidak terhambat. Penelitian ini bertujuan untuk mengetahui pengaruh pemberian ekstrak kacang hijau terhadap organoleptik Nata de cassava dari limbah kulit singkong.

\section{METODE PENELITIAN}

Penelitian ini menggunakan metode eksperimen dengan melakukan eksperimen di Laboratorium Fakultas Matematika dan Ilmu Pengetahuan Alam (FMIPA), Pekanbaru. Pengambilan sampel dilakukan dengan Rancangan Acak Lengkap (RAL) yang terdiri atas 4 perlakuan dan 3 ulangan. Parameter dalam penelitian ini adalah uji organoleptik. Berdasarkan hasil penelitian pemberian ekstrak kacang hijau sebesar $600 \mathrm{ml}$ memberikan peningkatan terhadap organoleptik Nata de cassava yang paling baik. Alat yang digunakan dalam penelitian ini adalah nampan, panci, kompor, kertas koran, kain lap, saringan, kain kasa, karet, pengaduk, sendok, neraca analitik, $\mathrm{pH}$ meter, ceret ukur, jangka sorong, angket organoleptik dan kamera. Bahan yang digunakan dalam penelitian ini adalah limbah kulit singkong yang telah dibesihkan setelah itu diblender, bakteri Acetobacter xylinum, kacang hijau yang telah dibersihkan lalu diblender, asam asetat, dan akuades.

\section{HASIL DAN PEMBAHASAN}

\section{Organoleptik Nata de cassava}

Organoleptik memiliki aspek yang akan diuji berupa aroma, rasa tekstur dan warna. Uji organoleptik terdiri dari uji mutu hedonik/uji deskriptif dan uji hedonik dengan melibatkan 10 orang responden/panelis, 5 orang mahasiswa dan 5 orang ibu rumah tangga. Dengan kriteria panelis yang sebelumnya dilatih untuk mengetahui sifatsifat tertentu dan memiliki tingkat kesukaan pada nata.

\section{Uji Mutu Hedonik}

\section{Tekstur Nata de cassava}

Berdasarkan hasil uji mutu hedonik didapatkan hasil pada tabel1 sebagai berikut.

Tabel 1. Hasil nilai organoleptik pada tekstur Nata de cassava

\begin{tabular}{|c|c|c|}
\hline $\begin{array}{c}\text { Perlakuan } \\
\text { pemberian } \\
\text { ekstrak kacang } \\
\text { hijau }(\mathrm{ml}) \\
\end{array}$ & $\begin{array}{c}\text { Nilai } \\
\text { Tekstur }\end{array}$ & Kategori \\
\hline A1: 300 & 2,60 & $\begin{array}{c}\text { Agak } \\
\text { Lembek }\end{array}$ \\
\hline $\mathrm{A} 2: 450$ & 3,60 & $\begin{array}{l}\text { Agak } \\
\text { Kenyal }\end{array}$ \\
\hline A3 : 600 & 4,23 & $\begin{array}{l}\text { Agak } \\
\text { Kenyal }\end{array}$ \\
\hline A4 : 750 & 2,20 & Lembek \\
\hline
\end{tabular}

Tabel 1 penilaian tekstur pada nata angka terendah diperoleh pada pemberian ekstrak kacang hijau perlakuan A4 dengan nilai panelis sebanyak 2,20 (lembek) hal ini disebabkan pada perlakuan A4 merupakan perlakuan yang diberikan ekstrak kacang hijau yang terlalu tinggi sehingga kelebihan nutrisi dalam pembentukan nata. Menurut Rindit Pambayun (2002) pada media 
fermentasi nata yang memiliki nitrogen yang berlebih akan mempengaruhi aktivitas pembentukan selulosa yang mengakibatkan produk nata yang dihasilkan memiliki tekstur yang kurang kompak atau lembek. Perlakuan A3 yang memiliki angka tertinggi dalam penilaian tekstur nata dengan nilai panelis sebayak 4,23 (agak kenyal) dikarenakan nata yang terbentuk mempunyai tekstur yang baik, pada saat penelitian nata ditekan dengan jari akan kembali seperti semula, kenyal dan tidak keras saat ditekan. Nata ini dapat terbentuk dengan tekstur yang baik dan kenyal karena dipengaruhi oleh kerapatan jaringan selulosa. Semakin rapat jaringan selulosa yang dihasilkan maka produk nata yang dihasilkan semakin kenyal, sedangkan semakin renggang jaringan selulosa yang dihasilkan maka produk nata semakin mudah hancur. Pembentukan nata dibutuhkan nutrisi yang cukup untuk merangsang metabolisme pertumbuhan bakteri Acetobacter xylinum sehingga dihasilkan nata yang baik dengan tekstur yang diinginkan Secara keseluruhan tekstur nata perlakuan A3 berada pada kriteria yang diinginkan.

\section{Warna Nata de cassava}

Berdasarkan hasil uji mutu hedonik perlakuan A1, A2, A3, dan A4 rata-rata berkisar 3,46-4,63 (kategori putih kekuningan hingga putih). Didapatkan hasil pada tabel 2 sebagai berikut.

Tabel 2. Hasil nilai organoleptik pada warna Nata de cassava

\begin{tabular}{ccc}
\hline $\begin{array}{c}\text { Perlakuan } \\
\text { pemberian } \\
\text { ekstrak } \\
\text { kacang }\end{array}$ & $\begin{array}{c}\text { Nilai } \\
\text { warna }\end{array}$ & Kategori \\
hijau(ml) & & \\
\hline A1 $: 300$ & 3,56 & Agak Putih \\
A2 $: 450$ & 3,73 & Agak Putih \\
A3 $: 600$ & 4,63 & Putih \\
A4: 750 & 3,46 & $\begin{array}{c}\text { Putih } \\
\text { Kekuningan }\end{array}$ \\
\hline
\end{tabular}

Tabel 2 penilaian panelis pada warna nata diperoleh nilai tertinggi pada perlakuan A3 dengan penilaian panelis sebanyak 4,63 (kategori putih). Sedangkan penilaian panelis pada warna nata diperoleh nilai terendah pada perlakuan A4 (kategori putih kekuningan) sebesar 3,46. Hal ini disebabkan warna yang dihasilkan nata dengan pemberian ektrak kacang hijau yang terlalu tinggi cenderung memiliki warna yang keruh, hal tersebut dikarenakan warna dari ekstrak kacang hijau yang dapat mempengaruhi warna nata pada proses pembentukan lapisan selulosa saat fermentasi. Ekstrak kacang hijau mempengaruhi ketebalan nata dan ketebalan akan berpengaruh terhadap warna nata. Perlakuan A3 yang merupakan nilai tertinggi menghasilkan warna putih yang berasal dari ekstrak limbah kulit singkong yang berwarna putih dan penambahan ekstrak kacang hijau sebesar $600 \mathrm{ml}$ yang merupakan pemberian ekstrak kacang hijau yang tidak berlebihan sehingga warna tersebut tidak terlalu terang dan tidak pula terlalu gelap. Hal ini disebabkan juga karena lembaran nata yang dihasilkan tebal dari perlakuan yang lainnya. Menurut Nurlinda (2015) pada uji organoleptik warna nata dipengaruhi oleh ketebalannya, dimana nata yang lebih tebal akan menghasilkan warna yang kurang cerah dibandingkan nata yang tipis, dari penilaian panelis warna yang baik diperoleh pada perlakuan A3.

\section{Aroma Nata de cassava}

Berdasarkan hasil penilaian yang diberikan panelis pada aroma dapat dilihat pada tabel 3 sebagai berikut.

Tabel 3. Hasil nilai organoleptik pada aroma Nata de cassava

\begin{tabular}{ccc}
\hline $\begin{array}{c}\text { Perlakuan } \\
\text { pemberian } \\
\text { ekstrak kacang } \\
\text { hijau (ml) }\end{array}$ & $\begin{array}{c}\text { Nilai } \\
\text { aroma }\end{array}$ & Kategori \\
\hline A1 $: 300$ & 2,83 & Berbau langu \\
A2 $: 450$ & 3,23 & $\begin{array}{c}\text { Berbau langu } \\
\text { Berbau khas } \\
\text { nata }\end{array}$ \\
A3 $: 600$ & 4,60 & Berbau langu \\
A4 : 750 & 2,63 & Tabel 3 menunjukkan penilaian aroma \\
\hline \multicolumn{3}{c}{ terendah diperoleh pada perlakuan A4 dengan } \\
penilaian sebesar 2,63 (kategori berbau \\
langu), sedangkan perlakuan A1 dan A2 juga \\
pada kategori berbau langu. Bau langu pada \\
nata yang dihasilkan merupakan pengaruh \\
penggunaan ekstrak kacang hijau. Bau langu
\end{tabular}


pada kacang hijau disebabkan adanya aktivitas enzim lipoksigenase yang secara alami terdapat didalam kacang-kacangan (Muchtadi, 1992). Penilaian aroma Nata de cassava angka tertinggi diperoleh pada perlakuan A3 dengan penilaian sebesar 4,60 (kategori berbau khas nata) disebabkan oleh jumlah pemberian ekstrak kacang hijau yang ditambahkan kedalam substrat sesuai.

\section{Rasa Nata de cassava}

Berdasarkan hasil penilaian yang diberikan panelis pada rasa dapat dilihat pada tabel 4 sebagai berikut.

Tabel 4 Hasil nilai organoleptik pada rasa Nata de cassava.

\begin{tabular}{ccc}
\hline $\begin{array}{c}\text { Perlakuan } \\
\text { pemberian } \\
\text { ekstrak kacang } \\
\text { hijau (ml) }\end{array}$ & $\begin{array}{c}\text { Nilai } \\
\text { rasa }\end{array}$ & Kategori \\
\hline A1 $: 300$ & 2,39 & Asam \\
A2 $: 450$ & 2,83 & Agak asam \\
A3 $: 600$ & 4,43 & Sedikit asam \\
A4: 750 & 1,79 & Asam \\
\hline
\end{tabular}

Tabel 4 menunjukkan penilaian rasa nata angka tertinggi diperoleh pada perlakuan A3 yaitu sebesar 4,43 (kategori sedikit asam) sedangkan penilaian rasa nata terendah diperoleh pada perlakuan A4 yaitu sebesar 1,79 (kategori asam). Hal ini dapat disebabkan oleh jumlah pemberian ekstrak kacang hijau yang ditambahkan berlebihan. Nitrogen yang ditambahkan akan dijadikan energi dan sisanya akan diubah menjadi asam asetat sehingga dapat mempengaruhi rasa nata. Semakin banyak nitrogen yang ditambahkan maka akan semakin tinggi kandungan asam asetat yang terdapat pada media.Rasa nata yang baik menurut SNI adalah hambar atau tidak terasa apapun setelah dilakukan proses perebusan nata. Tanggapan panelis yang paling tinggi terdapat pada perlakuan A3 dengan kategori sedikit asam. Hal tersebut dikarenakan pemberian ekstrak kacang hijau yang tidak terlalu tinggi dan juga tidak terlalu rendah. Rasa juga berhubungan dengan tingkat keasaman yang dihasilkan, semakin banyak asam asetat yang dihasilkan maka rasa nata cenderung asam sehingga konsumen tidak menyukai.

\section{Uji Hedonik Nata de cassava}

Hasil uji hedonik dapat dilihat pada tabel 5 sebagai berikut.

Tabel 5 Hasil nilai organoleptik pada uji hedonik Nata de cassava

\begin{tabular}{ccc}
\hline $\begin{array}{c}\text { Perlakuan } \\
\text { pemberian } \\
\text { ekstrak kacang } \\
\text { hijau (ml) }\end{array}$ & $\begin{array}{c}\text { Nilai uji } \\
\text { hedonik }\end{array}$ & Kategori \\
\hline A1 $: 300$ & 1,69 & Tidak suka \\
A2 $: 450$ & 1,90 & Tidak suka \\
A3 $: 600$ & 3,20 & Sedang \\
A4: 750 & 1,36 & Sangat tidak \\
& & suka \\
\hline
\end{tabular}

Tabel 5 menunjukkan penilaian panelis terhadap kesukaaan pada Nata de cassava tertinggi pada perlakuan A3 dengan penilaian panelis sebanyak 3,20 (kategori sedang) sedangkan penilaian panelis yang terendah pada tingkat kesukaan perlakuan A4 sebanyak 1,36 (kategori sangat tidak suka), hal ini disebabkan pada saat penelitian media perlakuan A4 diberikan ekstrak kacang hijau yang tinggi dan ketebalan yang dihasilkan tidak bagus. Menurut Maria Magdalena Melina (2016) konsentrasi $\mathrm{N}$ yang terlalu tinggi menyebabkan kinerja bakteri Acetobacter xylinum tidak efektif dalam mensintesa selulosa. Hal ini yang menyebabkan pada perlakukan A4 tidak tumbuh dengan baik nata tersebut sehingga penilaian panelis pada saat uji mutu sangat rendah. Perlakuan A3 merupakan nilai kesukaan tertinggi dari panelis dikarenakan tekstur nata agak kenyal, warna yang dihasilkan putih dan rasanya sedikit asam mendekati hambar, sehingga panelis memiliki tingkat kesukaan yang sedang. Pada saat penelitian panelis masih merasakan rasa yang tidak biasa pada nata karena tidak biasanya mengkonsumsi nata yang berasal dari limbah kulit singkong dan ditambahkan ekstrak kacang hijau, kebanyakan panelis lebih sering mengkonsumsi nata yang sering beredar dipasaran seperti Nata de coco, dari keseluruhan analisis ketebalan, $\mathrm{pH}$ dan uji organolpetik perlakuan $\mathrm{A} 3$ dengan pemberian ekstrak kacang hijau sebesar $600 \mathrm{ml}$ berada pada tingkat kualitas nata yang baik dan pada uji hedonik (kesukaan) berada pada kategori 
tingkat sedang. Pemberian ekstrak kacang hijau sebesar $600 \mathrm{ml}$ merupakan perlakuan yang terbaik karena pemberian ekstrak kacang hijau yang sesuai dengan pertumbuhan bakteri Acetobacter xylinum untuk tumbuh. Pemberian ekstrak kacang hijau sebesar 600 $\mathrm{ml}$ akan berpengaruh pada uji organoleptik dari segi tekstur, jika ketebalan nata sesuai dengan ketebalan yang diinginkan yaitu 1,5-2 $\mathrm{cm}$ maka tekstur yang didapatkan akan sangat baik. Hal ini akan berpengaruh terhadap warna yang dihasilkan, aroma dan rasa.

\section{KESIMPULAN}

Dari penelitian ini dapat disimpulkan bahwa pemberian ekstrak kacang hijau sebesar $600 \mathrm{ml}$ merupakan perlakuan yang menghasilkan organoleptik yang baik, pada hasil uji hedonik (kesukaan) berdasarkan uji mutu hedonik diperoleh dengan tingkat kesukaan sebesar 3,20 kategori sedang. Adapun saran dari penelitian ini yaitu menggunakan ekstrak kacang hijau sebesar $600 \mathrm{ml}$ untuk pembuatan nata dan dapat dilakukan pengujian terhadap parameter lainnya seperti ketebalan, $\mathrm{pH}$, kadar protein, kadar serat dan kadar karbohidrat untuk mengetahui nilai gizi Nata de cassava dari limbah kulit singkong.

\section{DAFTAR PUSTAKA}

Departemen Pertanian. 2011. Produksi Nata de cassava Dengan Substrat Limbah Cair Tapioka. Badan Litbang Pertanian. Jakarta Selatan.

Dewi lestari, Armansyah Putra, dan Wildan. 2018. Pengaruh limbah kulit singkong (manihot utilisima) terhadap kualitas nata de cassava. Jurnal Pendidikan dan Riset Biologi 1(1).

Elvi Rahmadan, Mirna Ilza, dan N.Ira Sari. 2017. Kajian Mutu Nata De pedada (Sonneratia Caseolaris) yang Diberi Ekstrak Tauge Berbeda. Jurnal
Fakultas Perikanan dan Kelautan. Universitas Riau. Pekanbaru.

Maria Magdalena Malina. 2016. Pengaruh Penggunaan Jus Kecambah Kacang Hijau Sebagai Sumber Nitrogen Alternatif Terhadap Karakteristik Nata de besusu. Skripsi yang tidak dipublikasikan. Universitas Sanata Dharma. Yogyakarta.

Nurlinda. 2015. Efektivitas penambahan gula terhadap kualitas nata de cassava dari limbah tapioka sebagai pengembangan modul pembelajaran pada konsep bioteknologi konvensional kelas XII SMA. Skripsi yang tidak dipublikasikan. Fakultas Keguruan dan Ilmu Pendidikan Universitas Riau. Pekanbaru.

Rindit Pambayun. 2002. Teknologi Pengolahan Nata de coco. Kanisius. Yogyakarta. 